\title{
Distribution records of aphids (Hemiptera: Phylloxeroidea, Aphidoidea) associated with main forest-forming trees in Northern Europe
}

\author{
Andrey V. Stekolshchikov \& Mikhail V. Kozlov
}

Stekolshchikov, A. V. \& Kozlov, M. V. 2012: Distribution records of aphids (Hemiptera: Phylloxeroidea, Aphidoidea) associated with main forest-forming trees in Northern Europe. — Entomol. Fennica 23: 206-214.

We report records of 25 species of aphids collected from four species of woody plants (Pinus sylvestris, Picea abies, Betula pubescens and B. pendula) at 50 study sites in Northern Europe, located from $59^{\circ}$ to $70^{\circ} \mathrm{N}$ and from $10^{\circ}$ to $60^{\circ} \mathrm{E}$. Critical evaluation of earlier publications demonstrated that in spite of the obvious limitations of our survey, the obtained information substantially contributed to the knowledge of the distribution of aphids in North European Russia, including Murmansk oblast (103 species recorded to date), Republic of Karelia (58 species), Arkhangelsk oblast (37 species), Vologda oblast (17 species) and Republic of Komi (29 species). We confirm the occurrence of Cinara nigritergi in Southern Karelia; Pineus cembrae, Cinara pilosa and Monaphis antennata are for the first time recorded in Norway.

A. V. Stekolshchikov, Zoological Institute, Russian Academy of Sciences, Universitetskaya nab.1, St. Petersburg 199034,Russia; E-mail: aphids@zin.ru

M. V. Kozlov, Section of Ecology, University of Turku, FI-20014 Turku, Finland; E-mail:mikoz@utu.fi

Received 2 February 2012, accepted 5 April 2012

\section{Introduction}

Species distributions and, consequently, spatial representations of biodiversity can only be assessed by analyzing the totality of species records. The georeferenced records (those that include map coordinates or allow accurate estimation of coordinates on the basis of verbal information) are vital for identifying and explaining distributional changes (Parmesan et al. 1999, Thomas 2005).

While entomologists in Finland and many other North European countries have collected and analyzed faunistic records of insects - often at very fine scales, up to $10 \times 10 \mathrm{~km}$ grid - for de- cades (e.g., Albrecht 2012), no comparable data (with rare exceptions) exist for the northern parts of the European Russia. This especially concerns aphids, which are rarely sampled by non-specialists and identification of which requires highly qualified taxonomic expertise. The only revision of aphids that covers North European Russia (Shaposhnikov 1967) is outdated and provides distributional data with very low spatial resolution. We are not aware of any published or webbased dot maps showing records of aphid species in Russia. Even the distribution ranges of pest aphids (e.g., maps in Afonin et al. 2008) are to a larger extent extrapolated rather than based on actual records. 


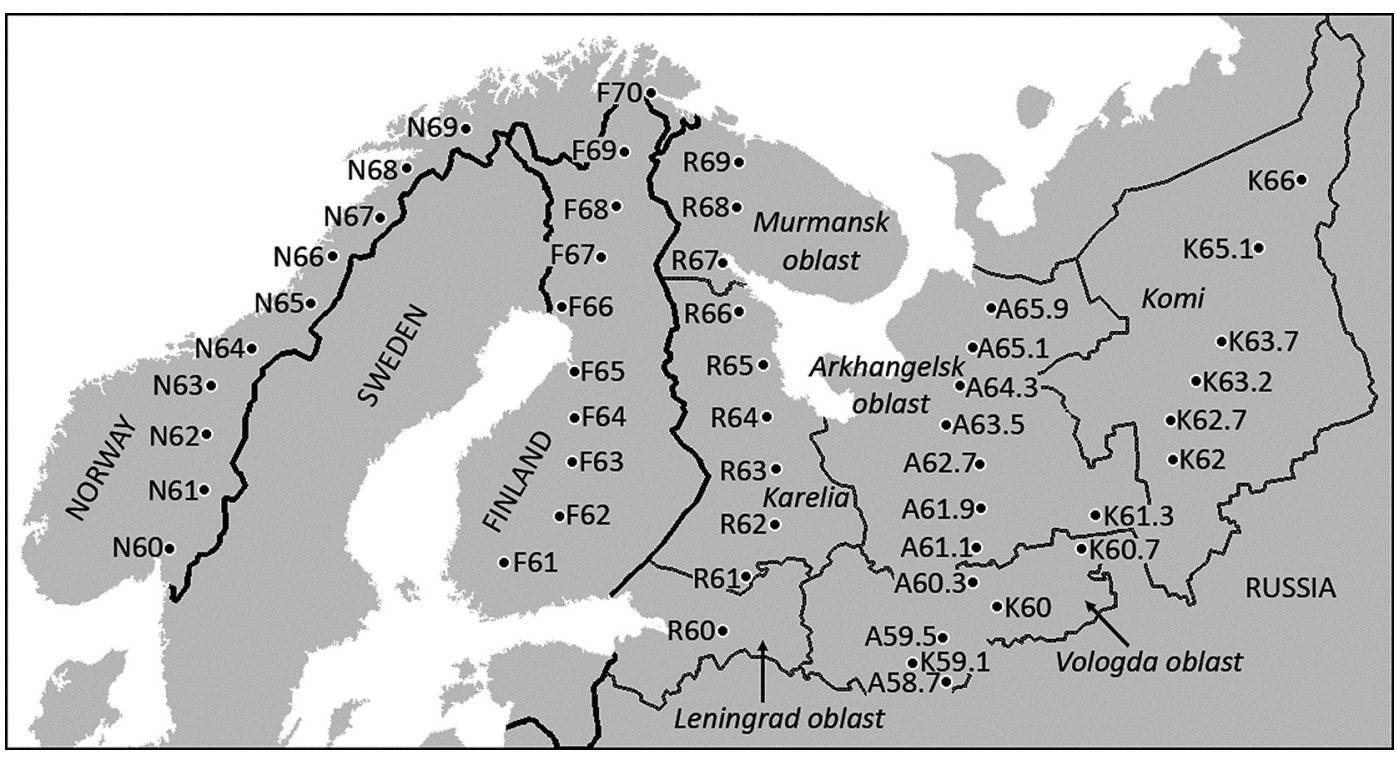

Fig. 1. Distribution of study sites in Northern Europe.

In the course of an ecological project addressing the levels of background herbivory on forestforming woody plants, the team led by M. Kozlov in 2008-2011 collected herbivorous insects from four tree species (Scots pine, Pinus sylvestris L.; Norway spruce, Picea abies (L.) Karst.; downy birch, Betula pubescens Ehrh.; white birch, $B$. pendula Roth.) at 50 sites in Northern Europe, located from $59^{\circ}$ to $70^{\circ} \mathrm{N}$ and from $10^{\circ}$ to $60^{\circ} \mathrm{E}$ (Fig. 1). All aphids found in these samples were identified by A. Stekolshchikov.

Although this sampling scheme, which includes only few species of host plants, poorly suits the goals of a faunistic inventory, the scarcity of data on the diversity of aphids in the northern parts of the European Russia justifies publication of the obtained records.

In addition, we briefly review publications by the Russian scientists (which are hard to access for researchers outside Russia) that contain faunistic information on aphids of Murmansk oblast, Republic of Karelia, Arkhangelsk oblast, Vologda oblast and Republic of Komi, and discuss the completeness of the faunistic information obtained in the course of our surveys. Data on aphid abundance will be published elsewhere.

\section{Material and methods}

Sampling was conducted along five latitudinal gradients (Fig. 1: N, in Norway; F, mostly within Finland; R, between St. Petersburg and Murmansk; A, between Vologda and Arkhangelsk; K, between Vologda and Inta). The sampling sites were located in forests typical for each geographical region. Care was taken to select representative sites where all four species of forest-forming trees (mentioned above) grow naturally. In some situations this was impossible, and therefore in 13 of 50 sampling sites we collected samples from three species and in two localities from only two species of trees (Table 1). In most study sites the sampled area did not exceed 2,000 $\mathrm{m}^{2}$. Samples from each site were collected twice per year $(\mathrm{N}$ gradient: 29.VI.-2.VII and 27.-30.VIII.2011; F gradient: 25.-26.VI and 2.-4.IX.2008; R gradient: 23.-29.VII and 21.-25.VIII.2008, 24.-29.VI and 24.-28.VIII.2009, 22.-27.VI and 29.VII.2.VIII.2010, 12.-16.VI and 10.-14.VIII.2011; A gradient: 16.-18.VI and 7.-9.VIII.2010; K gradient: 18.-20.VI and 1.-3.IX.2009).

Mature trees (generally aged 20 or more years) with lower branches that can be reached from the ground (i.e., within $2 \mathrm{~m}$ height) were selected on a "first found, first sampled" basis. At each site samples were collected from five trees 
Table 1. Geographical coordinates of sampling sites and numbers of aphid species collected from each host plant species at each site.

\begin{tabular}{|c|c|c|c|c|c|c|c|c|}
\hline \multirow{2}{*}{$\begin{array}{l}\text { Study } \\
\text { site }\end{array}$} & \multirow[t]{2}{*}{ Country $^{1}$} & \multirow{2}{*}{$\begin{array}{l}\text { Region or } \\
\text { provenance }^{2}\end{array}$} & \multicolumn{2}{|c|}{ Coordinates } & \multicolumn{4}{|c|}{ Numbers of aphid species ${ }^{3}$} \\
\hline & & & Latitude, N & Longitude, E & $\mathrm{sp}$ & pi & $\mathrm{db}$ & $w b$ \\
\hline N60 & NOR & AK & $59^{\circ} 47^{\prime} 34^{\prime \prime}$ & $10^{\circ} 45^{\prime} 35^{\prime \prime}$ & 1 & 2 & 2 & 0 \\
\hline N61 & NOR & $\mathrm{HE}$ & $61^{\circ} 04^{\prime} 40^{\prime \prime}$ & $11^{\circ} 20^{\prime} 46^{\prime \prime}$ & 0 & 0 & 4 & 2 \\
\hline N62 & NOR & $\mathrm{HE}$ & $62^{\circ} 04^{\prime} 19^{\prime \prime}$ & $10^{\circ} 42^{\prime} 40^{\prime \prime}$ & 1 & 1 & 2 & - \\
\hline N63 & NOR & ST & $62^{\circ} 59^{\prime} 28^{\prime \prime}$ & $10^{\circ} 15^{\prime} 50^{\prime \prime}$ & 0 & 2 & 2 & 3 \\
\hline N64 & NOR & NT & $63^{\circ} 54^{\prime} 15^{\prime \prime}$ & $11^{\circ} 26^{\prime} 25^{\prime \prime}$ & 1 & 2 & 2 & - \\
\hline N65 & NOR & NT & $65^{\circ} 04^{\prime} 19^{\prime \prime}$ & $13^{\circ} 18^{\prime} 15^{\prime \prime}$ & 1 & 1 & 1 & - \\
\hline N66 & NOR & Ns & $66^{\circ} 02^{\prime} 56^{\prime \prime}$ & $13^{\circ} 36^{\prime} 32^{\prime \prime}$ & 0 & 3 & 1 & - \\
\hline N67 & NOR & Ns & $66^{\circ} 59^{\prime} 44^{\prime \prime}$ & $15^{\circ} 20^{\prime} 22^{\prime \prime}$ & 2 & 0 & 2 & - \\
\hline N68 & NOR & $\mathrm{Nn}$ & $68^{\circ} 02^{\prime} 26^{\prime \prime}$ & $15^{\circ} 58^{\prime} 32^{\prime \prime}$ & 0 & 2 & 0 & - \\
\hline N69 & NOR & TR & $68^{\circ} 59^{\prime} 30^{\prime \prime}$ & $18^{\circ} 30^{\prime} 51^{\prime \prime}$ & 0 & 0 & 0 & - \\
\hline F61 & FIN & $\mathrm{Ta}$ & $61^{\circ} 00^{\prime} 27^{\prime \prime}$ & $23^{\circ} 30^{\prime} 42^{\prime \prime}$ & 3 & 3 & 4 & 3 \\
\hline F62 & FIN & $\mathrm{Ta}$ & $62^{\circ} 00^{\prime} 06^{\prime \prime}$ & $25^{\circ} 31^{\prime} 30^{\prime \prime}$ & 1 & 2 & 5 & 6 \\
\hline F63 & FIN & $\mathrm{Tb}$ & $63^{\circ} 03^{\prime} 14^{\prime \prime}$ & $25^{\circ} 49^{\prime} 33^{\prime \prime}$ & 1 & 1 & 5 & 5 \\
\hline F64 & FIN & $\mathrm{Om}$ & $63^{\circ} 53^{\prime} 48^{\prime \prime}$ & $25^{\circ} 47^{\prime} 52^{\prime \prime}$ & 0 & 2 & 2 & 4 \\
\hline F65 & FIN & Oba & $64^{\circ} 45^{\prime} 47^{\prime \prime}$ & $25^{\circ} 34^{\prime} 09^{\prime \prime}$ & 1 & 2 & 4 & - \\
\hline F66 & FIN & $\mathrm{Obb}$ & $65^{\circ} 58^{\prime} 32^{\prime \prime}$ & $24^{\circ} 39^{\prime} 49^{\prime \prime}$ & 2 & 1 & 2 & 3 \\
\hline F67 & FIN & Obb & $66^{\circ} 58^{\prime} 49^{\prime \prime}$ & $26^{\circ} 19^{\prime} 32 "$ & 0 & 0 & 2 & 1 \\
\hline F68 & FIN & Lkor & $67^{\circ} 58^{\prime} 35^{\prime \prime}$ & $26^{\circ} 50^{\prime} 53^{\prime \prime}$ & 1 & 1 & 1 & 1 \\
\hline F69 & FIN & $\mathrm{Li}$ & $69^{\circ} 00^{\prime} 41^{\prime \prime}$ & $27^{\circ} 00^{\prime} 39 "$ & - & 0 & 1 & 2 \\
\hline F70 & NOR & $\mathrm{F}$ & $70^{\circ} 04^{\prime} 41^{\prime \prime}$ & $27^{\circ} 59^{\prime} 22^{\prime \prime}$ & 0 & 0 & - & - \\
\hline R60 & RUS & Le & $59^{\circ} 58^{\prime} 26^{\prime \prime}$ & $32^{\circ} 11^{\prime} 46^{\prime \prime}$ & 4 & 3 & 4 & 6 \\
\hline R61 & RUS & $\mathrm{Ka}$ & $61^{\circ} 00^{\prime} 03^{\prime \prime}$ & $33^{\circ} 03^{\prime} 41^{\prime \prime}$ & 3 & 5 & 4 & 6 \\
\hline R62 & RUS & $\mathrm{Ka}$ & $61^{\circ} 58$ '51" & $34^{\circ} 14^{\prime} 27^{\prime \prime}$ & 2 & 3 & 7 & 5 \\
\hline R63 & RUS & $\mathrm{Ka}$ & $63^{\circ} 00^{\prime} 07^{\prime \prime}$ & $34^{\circ} 22^{\prime} 55^{\prime \prime}$ & 0 & 4 & 6 & 3 \\
\hline R64 & RUS & $\mathrm{Ka}$ & $64^{\circ} 01^{\prime} 44^{\prime \prime}$ & $34^{\circ} 04^{\prime} 11^{\prime \prime}$ & 1 & 1 & 2 & 3 \\
\hline R65 & RUS & $\mathrm{Ka}$ & $65^{\circ} 01^{\prime} 25^{\prime \prime}$ & $34^{\circ} 00^{\prime} 40^{\prime \prime}$ & 2 & 2 & 4 & 3 \\
\hline R66 & RUS & $\mathrm{Ka}$ & $66^{\circ} 01^{\prime} 57^{\prime \prime}$ & $32^{\circ} 59^{\prime} 13^{\prime \prime}$ & 1 & 4 & 4 & 2 \\
\hline R67 & RUS & $\mathrm{Mu}$ & $66^{\circ} 56^{\prime} 04^{\prime \prime}$ & $32^{\circ} 12^{\prime} 24^{\prime \prime}$ & 1 & 2 & 2 & 4 \\
\hline R68 & RUS & $\mathrm{Mu}$ & $68^{\circ} 01^{\prime} 05^{\prime \prime}$ & $32^{\circ} 57^{\prime} 07^{\prime \prime}$ & 5 & 3 & 4 & 3 \\
\hline R69 & RUS & $\mathrm{Mu}$ & $68^{\circ} 52^{\prime} 34^{\prime \prime}$ & $33^{\circ} 07^{\prime} 42^{\prime \prime}$ & 2 & 3 & 2 & - \\
\hline A58.7 & RUS & Vo & $58^{\circ} 40^{\prime} 55^{\prime \prime}$ & $40^{\circ} 18^{\prime} 35^{\prime \prime}$ & 0 & - & 1 & 1 \\
\hline A59.5 & RUS & Vo & $59^{\circ} 32^{\prime} 17^{\prime \prime}$ & $40^{\circ} 25^{\prime} 20^{\prime \prime}$ & 0 & 1 & 1 & 1 \\
\hline A60.3 & RUS & Vo & $60^{\circ} 29^{\prime} 04^{\prime \prime}$ & $41^{\circ} 48^{\prime} 50^{\prime \prime}$ & 1 & 2 & 3 & 3 \\
\hline A61.1 & RUS & $\mathrm{Ar}$ & $61^{\circ} 08^{\prime} 22^{\prime \prime}$ & $42^{\circ} 11^{\prime} 40^{\prime \prime}$ & 0 & 2 & 4 & 1 \\
\hline A61.9 & RUS & $\mathrm{Ar}$ & $61^{\circ} 51^{\prime} 49^{\prime \prime}$ & $42^{\circ} 38^{\prime} 01^{\prime \prime}$ & 1 & 0 & 1 & 4 \\
\hline A62.7 & RUS & $\mathrm{Ar}$ & $62^{\circ} 41^{\prime} 52^{\prime \prime}$ & $42^{\circ} 53^{\prime} 35^{\prime \prime}$ & 1 & 2 & 3 & 2 \\
\hline A63.5 & RUS & $\mathrm{Ar}$ & $63^{\circ} 30^{\prime} 59^{\prime \prime}$ & $41^{\circ} 42^{\prime} 55^{\prime \prime}$ & 0 & 2 & 3 & 4 \\
\hline A64.3 & RUS & $\mathrm{Ar}$ & $64^{\circ} 13^{\prime} 25^{\prime \prime}$ & $42^{\circ} 37^{\prime} 44^{\prime \prime}$ & 0 & 2 & 1 & 1 \\
\hline A65.1 & RUS & $\mathrm{Ar}$ & $64^{\circ} 54^{\prime} 21^{\prime \prime}$ & $43^{\circ} 31^{\prime} 03^{\prime \prime}$ & 1 & 2 & 1 & 2 \\
\hline A65.9 & RUS & $\mathrm{Ar}$ & $65^{\circ} 34^{\prime} 27^{\prime \prime}$ & $44^{\circ} 37^{\prime} 35^{\prime \prime}$ & 0 & 1 & 2 & - \\
\hline K59.1 & RUS & Vo & $59^{\circ} 07^{\prime} 31^{\prime \prime}$ & $39^{\circ} 11^{\prime} 26^{\prime \prime}$ & 0 & 3 & 0 & 2 \\
\hline K60 & RUS & Vo & $59^{\circ} 57^{\prime} 11^{\prime \prime}$ & $42^{\circ} 37^{\prime} 07^{\prime \prime}$ & 1 & 0 & 3 & 3 \\
\hline K60.7 & RUS & Vo & $60^{\circ} 43^{\prime} 13^{\prime \prime}$ & $46^{\circ} 14^{\prime} 51^{\prime \prime}$ & 2 & 2 & 1 & 1 \\
\hline K61.3 & RUS & $\mathrm{Ar}$ & $61^{\circ} 16^{\prime} 35^{\prime \prime}$ & $47^{\circ} 04^{\prime} 04^{\prime \prime}$ & 0 & 1 & 2 & 3 \\
\hline K62 & RUS & $\mathrm{Km}$ & $61^{\circ} 55^{\prime} 37^{\prime \prime}$ & $50^{\circ} 40^{\prime} 47^{\prime \prime}$ & 1 & 2 & 3 & 3 \\
\hline K62.7 & RUS & $\mathrm{Km}$ & $62^{\circ} 38^{\prime} 42^{\prime \prime}$ & $51^{\circ} 03^{\prime} 52 "$ & 2 & 2 & 5 & 4 \\
\hline K63.2 & RUS & $\mathrm{Km}$ & $63^{\circ} 11^{\prime} 32^{\prime \prime}$ & $52^{\circ} 38^{\prime} 30^{\prime \prime}$ & 0 & 2 & 2 & 2 \\
\hline K63.7 & RUS & $\mathrm{Km}$ & $63^{\circ} 44^{\prime} 14^{\prime \prime}$ & $54^{\circ} 12^{\prime} 43^{\prime \prime}$ & 1 & 4 & 0 & 2 \\
\hline K65.1 & RUS & $\mathrm{Km}$ & $65^{\circ} 08^{\prime} 33^{\prime \prime}$ & $57^{\circ} 16^{\prime} 22^{\prime \prime}$ & 1 & 2 & 2 & - \\
\hline K66 & RUS & $\mathrm{Km}$ & $66^{\circ} 00^{\prime} 16^{\prime \prime}$ & $60^{\circ} 20^{\prime} 14^{\prime \prime}$ & 0 & - & 6 & - \\
\hline
\end{tabular}

1 FIN, Finland; NOR, Norway; RUS, Russia.

2 Regions of Russia: Ar, Arkhangelsk oblast; Ka, Republic of Kareila; Km, Republic of Komi; Le, Leningrad oblast; Mu, Murmansk oblast; Vo, Vologda oblast. Abbreviations of provenances of Finland and Norway after Heie (1995).

3 Host plants: sp, Picea abies; pi, Pinus sylvestris; db, Betula pubescens; wb, B. pendula. 
of each species at each sampling date. The sampled trees were not tagged, and therefore early and late summer samples were generally collected from different trees. One branch (that can be accessed without disturbing the insects feeding on it) of about $50 \mathrm{~cm}$ in length (with approximately 80 leaves in birches, or 500 needle pairs in Scots pine, or 4,000 needles in spruce) was selected on a tree. One of two collectors placed a mesh bag attached to a ring ( $60 \mathrm{~cm}$ diameter) under the selected branch and the second collector cut the branch in such a way that it fell down into the bag together with insects that dropped from the branch when disturbed. The bag was immediately closed, labeled, and transported to the laboratory where all invertebrates were thoroughly collected and preserved in alcohol.

Total of 12,636 aphids were found in 995 samples; 1,995 samples did not contain aphids. The number of aphid individuals in a sample varied from 1 to 2,189 (with the median value of 3); 751 samples contained adults (apterous or alatae viviparous females, or males, or oviparous females). All adults and some nymphs (e.g., those of Monaphis antennata) were identified to the species. All specimens (including 1,488 slides prepared using Faure-Berlese mounting fluid) are deposited in the Zoological Institute of the Russian Academy of Sciences (St. Petersburg).

\section{List of species}

The list below contains information on the study site(s) where the species was recorded, and on the plant species from which it was sampled. Aphid nomenclature follows Remaudière \& Remaudière (1997) with subsequent additions (Eastop \& Blackman 2005, Holman 2009, Blackman \& Eastop 2011). Each site code consists of the letter indicating one of the five gradients (Fig. 1) and the approximate latitude $\left({ }^{\circ} \mathrm{N}\right)$. For exact co-ordinates of the study sites, plants sampled and number of aphid species found at each site, consult Table 1.

The study sites in the list are preceded by the abbreviated information on the geographical region (Ar, Arkhangelsk oblast; FIN, Finland; Ka, Republic of Karelia; Km, Republic of Komi; Le, Leningrad oblast; Mu, Murmansk oblast; NOR,
Norway; RUS, Russia; Vo, Vologda oblast); an asterisk $(*)$ denotes that the species had not been recorded from this region earlier. Adash indicates that the species was also found in all sites located between those connected by a dash. Information on host plant(s) is shown in parentheses: pi, Pinus sylvestris; sp, Picea abies; db, Betula pubescens; $\mathrm{wb}, B$. pendula. Information placed at the end of the line refers to all records, otherwise host plants are indicated for each individual record.

\subsection{Phylloxeroidea}

\subsubsection{Adelgidae}

Adelges laricis Vallot. RUS. Mu: R67-R69 (sp). Aphrastasia pectinatae (Cholodkovsky). RUS. Mu*: R68 (sp).

Pineus cembrae (Cholodkovsky). NOR*. N67. RUS. Ar*: A61.9 (sp).

\subsection{Aphidoidea}

\subsubsection{Lachnidae}

Cinara costata (Zettersted). FIN. F61. RUS. Le: R60; Ka*: R61, R64, R65; Mu*: R68 (sp).

Cinara nigritergi Mamontova. RUS. Ka*: R61, R63 (pi).

Cinara piceicola (Cholodkovsky). NOR. N62. FIN. F61. RUS. Le: R60; Ka*: R62; Ar*: A65.1; Km*: K62, K65.1 (sp).

Cinara pilicornis (Hartig). NOR. N60, N64, N65, N67. FIN. F61, F63, F65, F66. RUS. Le: R60; Ka*: R61, R62, R66; Mu: R68; Vo*: K60, K60.7, A60.3; Ar*: A62.7; Km*: K62.7, K63.7 (sp).

Cinara pilosa (Zettersted). NOR*. N66. RUS. Ka*: R61, R62, R66 (pi).

Cinara pinea (Mordvilko). NOR. N60, N62N64, N66, N68. FIN. F61, F62, F65. RUS. Le: R60; Ka*: R61, R65, R66; Mu: R67R69; Vo*: K59.1; Ar*: A62.7, A63.5; Km: K63.7, K65.1 (pi).

Cinara pini (Linnaeus). NOR. N68. FIN. F64. RUS. Le: R60; Ka*: R63; Ar*: A64.3; Km*: K62, K63.7 (pi).

Cinara pruinosa (Hartig). FIN. F66 (sp). 
Eulachnus agilis (Kaltenbach). FIN. F61. RUS. Ka: R61-R63, R66; Mu: R68, R69; Vo*: K59.1, K60.7, A60.3; Ar*: A61.1, A65.1, A65.9; Km*: K62-K65.1 (pi).

Schizolachnus pineti (Fabricius). NOR. N60, N63-N66. FIN. F61-F66, F68. RUS. Le: R60; Ka: R61- R66; Mu: R67-R69; Vo*: K59.1, K60.7, A59.5, A60.3; Ar*: K61.3, A61.1, A62.7-A65.1; Km*: K62.7-K63.7 (pi).

\subsubsection{Hormaphididae}

Hamamelistes betulinus (Horvath). RUS. Ka: R62 (db), R64-R65 (wb), R66 (db); Mu: R69 (db); Vo*: K60 (db); Ar*: A61.9 (wb).

\subsubsection{Drepanosiphidae}

Betulaphis quadrituberculata (Kaltenbach). NOR. N61 (db), N64-N65 (db), N67 (db). FIN. F61 (db), F63 (db), F64 (wb), F66-F67 (db), F69 (db). RUS. Le: R60 (wb); Ka*: R61-R63 (wb, db); Mu: R67 (wb), R68 (db); Vo*: K60 (wb), K60.7 (db); Ar*: K61.3 (wb, db), A61.1 (db), A61.9 (wb); Km*: K62 (db), K62.7 (wb, db), K63.7 (wb), K65.1-K66 (db).

Calaphis flava (Mordvilko). NOR. N60-N61 (db), N63-N64 (db). FIN. F61-F63 (wb, db), F64-F66 (db), F69 (wb). RUS. Le: R60 (db); Ka*: R61 (wb, db), R62-R63 (db), R65 (db); Mu: R68 (db); Vo*: K60 (db), A58.7-A60.3 (db); Ar*: A61.1 (db), A62.7 (db), A63.5 (wb, db), A64.3 (db); Km: K62 (wb), K62.7 (wb, db).

Calaphis betulicola (Kaltenbach). FIN. F62 (wb).

Callipterinella calliptera (Hartig). FIN. F61 (db), F66 (wb). RUS. Le: R60 (wb); Vo*: K60 (db); Ar*: A63.5 (wb), A65.9 (db); Km*: K62-K62.7 (db), K63.2 (wb, db).

Callipterinella tuberculata (von Heyden). FIN. F62. RUS. Le: R60; Ka: R61-R62; Mu: R67; Vo*: A60.3; Km*: K63.7 (wb).

Clethrobius comes (Walker). FIN. F67 (wb).

RUS. Ka*: R62 (wb, db); Mu: R68 (wb); Vo*: A60.3 (db); Ar*: K61.3 (wb).

Euceraphis betulae (Koch). NOR. N61 (wb, db),
N63 (wb). FIN. F61 (wb), F62-F63 (wb, db), F64 (wb), F66 (wb), F68 (wb). RUS. Le: R60 (wb, db ); Ka*: R61-R62 (wb), R63-R66 (wb, db); Mu: R67-R68 (wb, db); Vo*: K59.1-K60.7 (wb), A58.7-A60.3 (wb); Ar: K61.3 (wb, db), A61.1 (wb, db), A61.9 (wb), A62.7-A63.5 (wb, db), A64.3 (wb), A65.1 (wb, db); Km*: K62-K63.2 (wb).

Euceraphis punctipennis (Zettersted). NOR. N61-N63 (db), N66 (db), F70 (db). FIN. F61-F62 (wb, db), F63 (wb), F64 (wb, db), F65 (db), F66 (wb). RUS. Le: R60 (wb, db ); Ka: R61-R66 (wb, db); Mu: R67-R68 (wb, db), R69 (db); Vo*: K59.1 (wb), A60.3 (wb, db); Ar*: A61.1 (db), A61.9-A63.5 (wb, db), A65.1 (wb), A65.9 (db); Km: K62 (wb), K62.7 (db), K65.1 (db).

Monaphis antennata (Kaltenbach). NOR*. N60 (db). FIN. F62-F63 (wb, db), F65 (db). RUS. Le: R60 (db ); Ka*: R61 (wb, db), R62-R63 (db), R65-R66 (db); Km*: K62-K63.2 (db).

Symydobius oblongus (von Heyden). NOR. N61 (wb), N62 (db), N67 (db). FIN. F62 (db), F63 (wb, db), F64 (wb), F65 (db), F67-F68 (db), F69 (wb). RUS. Le: R60 (wb); Ka: R62-R63 (db); Vo*: K60 (wb); Km*: K62.7 (wb).

\subsubsection{Aphididae}

Elatobium abietinum (Walker). FIN. F62, F68. RUS. Le: R60; Ka*: R61, R65; Mu: R68R69; Vo*: K60.7; Km*: K62.7 (sp).

\section{Discussion}

\subsection{Completeness of faunistic inventory}

A comparison of the catalogue by Holman (2009) with the list of species recorded from Finland (Albrecht 2012) demonstrated that 45 aphid species can be found in Finland on the tree species investigated by us. During our survey of 2008 we recorded 18 species, i.e. $40 \%$ of the potential fauna. On the basis of this comparison we conclude that for the sampled regions of Russia our inventory revealed between one-quarter and onehalf of aphid fauna associated with the investigated tree species. 
Table 2. Summary of publications reporting faunistic information on aphids for North European Russia.

\begin{tabular}{|c|c|c|c|c|c|}
\hline \multirow[t]{2}{*}{ Region } & \multirow[t]{2}{*}{ Reference } & \multirow[t]{2}{*}{ Study type } & \multicolumn{2}{|c|}{ Data quality } & \multirow{2}{*}{$\begin{array}{l}\text { No. of } \\
\text { species }\end{array}$} \\
\hline & & & Identifications & Localities* & \\
\hline \multirow{19}{*}{$\begin{array}{l}\text { Murmansk } \\
\text { oblast }\end{array}$} & Nesterchuk 1930 & Applied & Questionable & Exact & 1 \\
\hline & Mordvilko 1935 & Faunistic & OK & Approximate & 13 \\
\hline & Znamenskaya \& Zanadvorova 1934 & Applied & Questionable & Exact & 1 \\
\hline & Fridolin 1935 & Faunistic & OK & Exact & 1 \\
\hline & Fridolin 1936 & Ecological & Questionable & Exact & 16 \\
\hline & Znamenskaya 1941, 1962 & Applied & OK & Exact & 8 \\
\hline & Znamenskaya 1961 & Applied & OK & Not reported & 3 \\
\hline & Novitskaya 1962 & Applied & OK & Exact & 9 \\
\hline & Shaposhnikov 1967 & Revisionary & OK & Approximate & 35 \\
\hline & Vershinina 1972, 1975, 1981 & Applied & Questionable & Not reported & 12 \\
\hline & Rupais 1985 & Faunistic & OK & Exact & 1 \\
\hline & Heie 1986, 1992, 1994, 1995 & Faunistic & OK & Not reported & 24 \\
\hline & Vershinina \& Rak 1993 & Applied & Questionable & Not reported & 4 \\
\hline & Buga 1999 & Faunistic & OK & Exact & 18 \\
\hline & Rak et al. 2001 & Applied & Questionable & Exact & 4 \\
\hline & Mitina \& Kuznetsova 2006 & Faunistic & Questionable & Exact & 1 \\
\hline & Stekolshchikov \& Buga 2006 & Morphological & OK & Exact & 1 \\
\hline & Rak \& Litvinova 2010 & Applied & Questionable & Exact & 5 \\
\hline & Stekolshchikov 2012 & Faunistic & OK & Exact & 68 \\
\hline \multirow{6}{*}{$\begin{array}{l}\text { Republic } \\
\text { of Karelia }\end{array}$} & Shaposhnikov 1972 & Applied & $\mathrm{OK}$ & Not reported & 1 \\
\hline & Heie 1980, 1982, 1986, 1992, 1994, 1995 & Faunistic & OK & Not reported & 31 \\
\hline & Stekolshchikov et al. 1998 & Ecological & OK & Exact & 1 \\
\hline & Kutenkova 1991 & Ecological & Questionable & Exact & 3 \\
\hline & Kutenkova 2011 & Faunistic & Questionable & Exact & 15 \\
\hline & Stekolshchikov 2011 & Faunistic & OK & Exact & 1 \\
\hline \multirow{3}{*}{$\begin{array}{l}\text { Arkhangelsk } \\
\text { oblast }\end{array}$} & Ezhov 2008, Burak \& Ezhov 2009, 2010 & Applied & Questionable & Approximate & 10 \\
\hline & Burak 2010, Ezhov \& Burak 2010 & Applied & Questionable & Exact & 18 \\
\hline & Starkovskiy \& Zorin 2010 & Applied & Questionable & Not reported & 2 \\
\hline \multirow{2}{*}{$\begin{array}{l}\text { Vologda } \\
\text { oblast }\end{array}$} & Starkovskiy \& Zorin 2010 & Applied & Questionable & Not reported & 2 \\
\hline & Vasilieva \& Stepanova 2011 & Applied & Questionable & Exact & 1 \\
\hline Republic & Sedykh 1974 & Faunistic & Questionable & Approximate & 4 \\
\hline \multirow{6}{*}{ of Komi } & Yurkina 2000a, 2001 & Ecological & Questionable & Not reported & 7 \\
\hline & Yurkina 2000b & Ecological & Questionable & Not reported & 3 \\
\hline & Yurkina 2003 & Ecological & Questionable & Not reported & 1 \\
\hline & Yurkina 2007 & Ecological & Questionable & Not reported & 13 \\
\hline & Yurkina \& Strekalova 2011 & Ecological & Questionable & Not reported & 16 \\
\hline & Mingaleva \& Pestov 2011 & Applied & OK & Approximate & 1 \\
\hline
\end{tabular}

* Exact: position of the sampling site can be attributed to $10 \times 10 \mathrm{~km}$ area; approximate: can be attributed to $50 \times 50 \mathrm{~km}$ area.

\subsection{Present faunistic knowledge of aphids of North European Russia}

An analysis of publications which contain information on aphids collected from the administrative regions covered by our surveys (except for Leningrad oblast) demonstrated that most of the authors did not provide exact locality data, and that the reliability of species identification is generally low (Table2). The identifications by some researchers (Mitina \& Kuznetsova 2006, Burak \& Ezhov 2009, 2011, Ezhov \& Burak 2010, Mingaleva \& Pestov 2011) are based on a combination of the host plant identity and external appearance of the aphids, and no voucher specimens have been preserved. Although even under 
these circumstances there is a probability of correct identification, this practice is likely to end up with false records and should therefore be discontinued.

Compared to Finland and Norway, with 477 (Albrecht 2012) and 344 species of aphids recorded to date (Nieto Nafria et al. 2011), aphid fauna of North European Russia is poorly known. The total numbers of aphid species recorded from the regions covered by our survey are as follows (in parentheses: proportion of new records relative to the number of previously known species): Murmansk oblast $103(+2 \%)$, Republic of Karelia $58(+32 \%)$, Arkhangelsk oblast $37(+61 \%$, including Cavariella pastinacae (L.) occasionally sampled from birch at A61.9), Vologda oblast 17 $(+467 \%)$, Republic of Komi 29 (+53\%). Thus, our survey, in spite of its obvious incompleteness, substantially increased the knowledge of the distribution of aphids in northern taiga and subarctic forests of European Russia. Moreover, we found three species that have not yet been reported from Norway (Pineus cembrae, Cinara pilosa and Monaphis antennata).

Most recorded species are common throughout their distribution ranges, thus finding them in the study regions was more or less predictable. However, the discovery of Cinara nigritergi (for diagnostic features consult Stekolshchikov 2011) in Southern Karelia (site R63) was somewhat astonishing. Noteworthy, when the mentioned paper was already in print, additional specimens were identified in samples from another locality (R61), confirming the occurrence of this species in Karelia. Recently, C. nigritergi was also discovered in Finland (A. Albrecht, pers. comm.). It seems likely that this species is relatively common but overlooked in many parts of its distribution range.

Thus, even incomplete surveys conducted for the reasons other than faunistic research contributed substantially to the knowledge of aphids of Northern Europe, especially of the Russian parts of it. The discovery of one species new for the region (C. nigritergi) and addition of three species to the well-known fauna of Norway hint that selection of sampling sites driven by reasons other than "entomologist's internal algorithm" (intuition) may occasionally yield interesting faunistic information.
Acknowledgements. We thank V. Zverev, E. Zvereva, N. Zvereva, A. Popova, M. Inozemtseva and L. Krasheninin for fieldwork and laboratory assistance, and A. Albrecht, R. Rakauskas, G. Söderman and E. Zvereva for commenting an earlier version of the manuscript. The study was supported by the Academy of Finland (project 122133 and the researcher exchange grants), Russian Academy of Sciences (Program "Biodiversity: state and dynamics"), and by a strategic research grant from the University of Turku.

\section{References}

Afonin, A. N., Greene, S. L., Dzyubenko, N. I. \& Frolov A. N. (eds.) 2008: Interactive agricultural ecological atlas of Russia and neighboring countries. Economic plants and their diseases, pests and weeds. [www document]. URL http://www.agroatlas.ru. (Site visited on 2 April, 2012). [In Russian.]

Albrecht, A. 2012: Atlas of the aphids of Finland. [www document]. URL http://www.luomus.fi/elaintiede/ hyonteiset/tutkimus/kirvat/atlas.htm. (Site visited on 2 April, 2012).

Blackman, R. L. \& Eastop, V. F. 2011: Additions and amendments to "Aphids on the World's Plants". Zootaxa 2774: 57-68.

Buga, S. V. 1999: Aphids (Homoptera, Aphidinea) feeding on woody plants in the Polar-Alpine Botanical Garden. - In: Dolgin, M. M. (ed.), Biodiversity of terrestrial and soil invertebrates in the North. Abstracts of international conference (Syktyvkar, 15-17 September 1999): 32-33. Syktyvkar State University, Syktyvkar. 227 pp. [In Russian.]

Burak, S. V. \& Ezhov, O. N. 2009: (Biodiversity of pests and diseases of green plantations in Arkhangelsk oblast.) - In: Taskaev, A. I. (ed.), Problems of study and protection of animals in the North: Proceedings of the All-Russian scientific conference with international participation (Syktyvkar, Komi Republic, Russia, November 16-20, 2009.): 250-252. Komi Science Centre, Syktyvkar. 387 pp. [In Russian.]

Burak, S. V. \& Ezhov, O. N. 2011: (Pests and diseases of planted trees and shrubs in Arkhangelsk oblast.) Plant Protection News 0(1): 46-50. [In Russian.]

Burak, S. V. 2010: (Species-specific leaf damage by pests of green plantations in the town of Mirnyi.) - In: Bogolitsyn, K. G. (ed.), Ecology of arctic and subarctic territories: Materials of international symposium, 610 June 2010: 319-322. Institute of Ecological Problems of the North, Arkhangelsk. 461 pp. [In Russian.]

Eastop, V. F. \& Blackman, R. L. 2005: Some new synonyms in Aphididae (Hemiptera: Sternorrhyncha). Zootaxa 1089: 1-36.

Ezhov, O. N. \& Burak, S. V. 2010: (Pests and diseases of trees and shrubs in arboretum of Arkhandgelsk State Technical University.) — Plant Protection News 0(2): 50-54. [In Russian.]

Ezhov, O. N. 2008: (Pests and diseases of urban green 
plantations in Arkhangelsk industrial hub.) — Forest Journal 0(3): 45-50. [In Russian.]

Fridolin, V. Ju. 1935: Koukiss-woum-tschorr, le plateau central des Monts Khibines au point de vue biocenotique. - Entomologicheskoe Obozrenie 26: 165-182.

Fridolin, V. Ju. 1936: (Community of animals and plants of Khibiny mountain area. Biocenotical investigations in 1930-1935.) - Academy of Sciences of the USSR, Moscow \& Leningrad. 295 pp. [In Russian.]

Heie, O. E. 1980: The Aphidoidea (Hemiptera) of Fennoscandia and Denmark: I. The families Mindaridae, Hormaphididae, Thelaxidae, Anoeciidae, and Pemphigidae. - Fauna Entomologica Scandinavica 9: 1247.

Heie, O. E. 1982: The Aphidoidea (Hemiptera) of Fennoscandia and Denmark: II. The family Drepanosiphidae. - Fauna Entomologica Scandinavica 11: 1-176.

Heie, O. E. 1986: The Aphidoidea (Hemiptera) of Fennoscandia and Denmark: III. Family Aphididae: Subfamily Pterocommatinae and Tribe Aphidini of Subfamily Aphidinae. - Fauna Entomologica Scandinavica 17: 1-314.

Heie, O. E. 1992: The Aphidoidea (Hemiptera) of Fennoscandia and Denmark: IV. Family Aphididae: Part 1 of Tribe Macrosiphini of Subfamily Aphidinae. - Fauna Entomologica Scandinavica 25: 1-189.

Heie, O. E. 1994: The Aphidoidea (Hemiptera) of Fennoscandia and Denmark: V. Family Aphididae: Part 2 of Tribe Macrosiphini of Subfamily Aphidinae. - Fauna Entomologica Scandinavica 28: 1-239.

Heie, O. E. 1995: The Aphidoidea (Hemiptera) of Fennoscandia and Denmark. V. Family Aphididae: Part 3 of Tribe Macrosiphini of Subfamily Aphidinae, and family Lachnidae. - Fauna Entomologica Scandinavica 31: 1-222.

Holman, J. 2009: Host plant catalog of aphids: Paleartic region. - Springer, Netherlands. $1140 \mathrm{pp}$.

Kutenkova, N. N. 1991: (Communities of invertebrates in birch canopies and use of food resources by these invertebrates) - In: Yakovlev, E. B. \& Mozolevskaya E. G. (eds.), Entomological studies in the "Kivatch" reserve: 75-98. Forest Institute, Petrozavodsk. 155 pp. [In Russian.]

Kutenkova, N. N. 2011: (The phytophagous insects inhabiting crowns of trees and shrubs, and associated entomophagous species in the "Kivatch" nature reserve.) - Proceedings of the State nature Reserve "Kivatch" 5: 104-154. [In Russian.]

Mingaleva, N. A. \& Pestov, S. V. 2011: (Evaluation of the state of poplars planted in the town of Syktyvkar.) Theoretical and Applied Ecology 0(1): 37-43. [In Russian.]

Mitina, E. G. \& Kuznetsova, O. M. 2006: (On the fauna of insect pests on trees and shrubs in the city of Murmansk.) - Scientific Transactions of Murmansk State Pedagogical University, Biological Sciences 2: 49-56. [In Russian.]

Mordvilko, A. K. 1935: Die Blattläuse mit unvollständigem Generationszyklus und ihre Entstehung. - Ergebnisse und Fortschritte der Zoologie 8: 36-328.
Nesterchuk, G. I. 1930: (Forests of Karelia and Murmansk region, and their pests.) - Plant Diseases 19(3-4): 159-181. [In Russian.]

Nieto Nafría, J. M., Andreev, A. V., Binazzi, A., Mier Durante, M. P., Pérez Hidalgo, N., Rakauskas, R. \& Stekolshchikov, A. V. 2011: Fauna Europaea: Phylloxeroidea, Aphidoidea. Fauna Europaea version 2.2. [www document]. URL http://www.faunaeur.org/. (Site visited on 4 January, 2012).

Novitskaya, L. A. 1962: (Overview of pests of woody plants in Murmansk oblast.) - In: Avrorin, N. A. (ed.), (Ornamental plants and landscape gardening in extreme North): 182-186. Academy of Sciences of the USSR, Moscow \& Leningrad. 202 pp. [In Russian.]

Parmesan, C., Ryrholm, N., Stefanescu, C., Hill, J. K., Thomas, C. D., Descimon, H., Huntley, B., Kaila, L., Kullberg, J., Tammaru, T., Tennent, W. J., Thomas, J. A. \& Warren, M. 1999: Poleward shifts in geographical ranges of butterfly species associated with regional warming. - Nature 399: 579-583.

Rak, N. S. \& Litvinova, S. V. 2010: (Migration and acclimatization of pests during introduction of plants in greenhouses in the Far North of Russia.) - Hortus Botanicus [www document]. URL http://hb.karelia.ru/. (Site visited on 13 January, 2012). [In Russian.]

Rak, N. S., Belyakova, N. A., Dorokhova, G. I. \& Krasavina, L. P. 2001: (Biological control of pests of flowers and ornamental plants in Zapolyarie.) - Proceedings of the Russian Entomological Society 72: 48-53. [In Russian.]

Remaudière, G. \& Remaudière, M. 1997: Catalogue of the word's Aphididae. - INRA editions, Paris. 474 pp.

Rupais, A. A. 1985: A new species of crowberry aphid (Aphidinea) from the Murmansk district. - Latvijas Entomologs 28: 54-57. [In Russian.]

Sedykh, K. F. 1974: (Animal world of the Komi Autonomous Republic. Invertebrates.) — Komi Publishing House, Syktyvkar. 189 pp. [In Russian.]

Shaposhnikov, G. Ch. 1967: Suborder Aphidinea-aphids. — In: Bei-Bienko, G. Ya. (ed.), Keys to the insects of the European USSR. 1. Apterygota, Palaeoptera, Hemimetabola: 616-766. Israel Program for Scientific Translation, Jerusalem. 1214 pp.

Shaposhnikov, G. Ch. 1972: Suborder Aphidinea-aphids. - In: Kryzhanovskii, O. L. (ed.), Insects and mites pests of agricultural crops. V. 1: 149-189. Nauka, Leningrad. 323 pp. [In Russian.]

Starkovskij, B. N. \& Zorin, D. P. 2010: (Pests of fireweed.) — Protection and Quarantine of Plants 0(5): 45-46. [In Russian.]

Stekolshchikov, A. V. 2011: Description of oviparous female of Cinara nigritergi Mamontova, 2002 (Hemiptera: Aphididae). — Entomologica Fennica 22: 209 212.

Stekolshchikov, A. V. 2012: (Annotated list of aphids (Homoptera, Aphidinea) of the Lapland Reserve.) - Proceeding of the Lapland State Nature Biosphere Reserve 6: 385-411. [In Russian.]

Stekolshchikov, A. V. \& Buga, S. V. 2006: Hitherto unknown morphs of Hyperomyzus (Neonasonovia) hie- 
racii (Börner, 1939) (Homoptera: Aphididae). —Zoosystematica Rossica 15: 57-62.

Stekolshchikov, A. V., Lemza, S. N. \& Shaposhnikov, G. Ch. 1998: Possibility of overcoming temporal and reproductive isolation between closely related aphid species (Homoptera, Aphididae). — Entomologicheskoe Obozrenie 77: 273-279. [In Russian.]

Tambs-Lyche, H. 1968: Studies on Norwegian aphids (Hom., Aphidoidea) 1. The subfamily Dactynotinae Börner. - Norsk entomologisk Tidsskrift 15: 1-17.

Tambs-Lyche, H. 1970: Studies on Norwegian aphids (Homoptera, Aphidoidea). II. The subfamily Myzinae (Mordvilko) Börner. - Norsk entomologisk Tidsskrift 17: 1-17.

Thomas, J. A. 2005: Monitoring change in the abundance and distribution of insects using butterflies and other indicator groups. - Philosophical Transactions of the Royal Society B - Biological Sciences 360: 339-357.

Vassilieva, T. A. \& Stepanova, L. Yu. 2011: (Pests of bird's-foot trefoil.) - Protection and Quarantine of Plants 0(3): 59-60. [In Russian.]

Vershinina, N. P. \& Rak, N. S. 1993: (Development of the biological control of plant pests in Zapolyarie.) - In: Viracheva, L. L. (ed.), (Introduction and protection of plants in Kola North): 81-90. Kola Science centre, Apatity. 125 pp [In Russian.]

Vershinina, N. P. 1972: (Most common pests of plants grown in greenhouses and houses in the Murmansk oblast, and plant protection measures.) - In: Kozupeeva, T. A. (ed.), (Problems of botanical research in Kola North): 105-108. Kola Branch of the Academy of Sciences of the USSR, Apatity. 137 pp. [In Russian.]

Vershinina, N. P. 1975: (Pests of green plantations in Murmansk oblast and protection nmeasures.) - In: Ramenskaya, M. L. \& Kozupeeva, T. A. (eds.), (Floristic research and formation of green plantations in the Kola Peninsula): 198-202. Kola Branch of the Academy of Sciences of the USSR, Apatity. 215 pp. [In Russian.]

Vershinina, N. P. 1981: (Pests of ornamental plants in Murmansk oblast.) — In: Andreev, G. N. (ed.), (Development of botanical research in Kola North): 138-147. Polar-Alpine Botanical Garden and Institute, Apatity. 153 pp. [In Russian.]

Yurkina, E. V. \& Pestov, S. V. 2009: (Phenological specificity of forest insects in mid-taiga subzone of the Republic of Komi.) - Theoretical and Applied Entomology 0(4): 83-91. [In Russian.]
Yurkina, E. V. 2000a: (Insect communities of Scots pine forests in taiga zone of the Republic of Komi.) - In: Pavlov, L. S. \& Shatunovskiy V. I. (eds.), (Investigation and protection of faunal, floral, and ecosystem diversity in Eurasia. Materials of international conference, Moscow, 21-23 April 1999): 264-270. A. N. Severtsov Institute of Ecology and Evolution, Moscow. 381 pp. [In Russian.]

Yurkina, E. V. 2000b: (Insects feeding on shrubs in midtaiga subzone of the Republic of Komi.) - In: Bolshakov, N. M. (ed.), (Scientific and technical progress in forest industry. Materials of international scientific and technical conference): 267-270. Syktyvkar Forest Institute, Syktyvkar. 314 pp.

Yurkina, E. V. 2001: (Arthropods feeding on leaf-bearing woody plants in mid-taiga subzone of the Republic of Komi.) — Proceedings of the Komi Scientific Centre 166: 52-62. [In Russian.]

Yurkina, E. V. 2003: (Regularities in formation of the arthropod fauna in Scots pine forests of mid- and southern taiga of European North-East.) - Bulletin of Moscow State Forest University - Forestry Bulletin 0(2): 175-184. [In Russian.]

Yurkina, E. V. 2007: (Fauna of sap-feeding arthropods of mid-taiga subzone of the Republic of Komi, with evaluation of their role in decline of Scots pine in recultivated areas.) - In: Archegova, I. B. (ed.), Development of the North and problems of nature rehabilitation. Presentations at 6 th international scientific conference (Syktyvkar, Republic of Komi, 10-14 October 2006): 152-161. Institute of Biology, Syktyvkar. 162 pp. [In Russian.]

Yurkina, E. V. \& Strekalova, E. G. 2011: (Sap-feeding insects as a part of natural, slightly disturbed and disturbed forests and artificaially created stands.) - Bulletin of Moscow State Forest University - Forestry Bulletin 0(4): 35-42. [In Russian.]

Znamenskaya, M. K. \& Zanadvorova, V. P. 1934: (Pests of vegetables grown in polar region.) - Problems of Northern Plant-Growing 4: 163-175. [In Russian.]

Znamenskaya, M. K. 1941: (Pest of cereals and forage grasses in Khibines.) - Bulletin of Plant Protection 0(1): 42-44. [In Russian.]

Znamenskaya, M. K. 1961: (Pests of berries in Murmansk oblast.) - Plant Protection from Pests and Diseases 0(8): 20-23. [In Russian.] 